\title{
Functional correlation of ATP1A2 mutations with phenotypic spectrum: from pure hemiplegic migraine to its variant forms
}

Yingji $\mathrm{Li}^{1+}$, Wenjing Tang ${ }^{1 \dagger}$, Li Kang ${ }^{1,2}$, Shanshan Kong ${ }^{1}$, Zhao Dong ${ }^{1}$, Dengfa Zhao ${ }^{1}$, Ruozhuo Liu ${ }^{1}$ and Shengyuan $\mathrm{Yu}^{1 *}$ (D)

\begin{abstract}
Background: Mutations in ATP1A2, the gene encoding the a2 subunit of $\mathrm{Na}^{+} / \mathrm{K}^{+}$-ATPase, are the main cause of familial hemiplegic migraine type 2 (FHM2). The clinical presentation of FHM2 with mutations in the same gene varies from pure FHM to severe forms with epilepsy and intellectual disability, but the correlation of these symptoms with different ATP1A2 mutations is still unclear.

Methods: Ten ATP1A2 missense mutations were selected according to different phenotypes of FHM patients. They caused pure FHM (FHM: R65W, R202Q, R593W, G762S), FHM with epilepsy (FHME: R548C, E825K, R938P), or FHM with epilepsy and intellectual disability (FHMEl: T378N, G615R, D718N). After ouabain resistance and fluorescence modification, plasmids carrying those mutations were transiently transfected into HEK293T and HeLa cells. The biochemical functions were studied including cell survival assays, membrane protein extraction, western blotting, and $\mathrm{Na}^{+} / \mathrm{K}^{+}$-ATPase activity tests. The electrophysiological functions of G762S, R938P, and G615R mutations were investigated in HEK293T cells using whole-cell patch-clamp. Homology modeling was performed to determine the locational distribution of ATP1A2 mutations.
\end{abstract}

Results: Compared with wild-type pumps, all mutations showed a similar level of protein expression and decreased cell viability in the presence of $1 \mu \mathrm{M}$ ouabain, and there was no significant difference among the mutant groups. The changes in $\mathrm{Na}^{+} / \mathrm{K}^{+}$-ATPase activity were correlated with the severity of FHM phenotypes. In the presence of $100 \mu \mathrm{M}$ ouabain, the $\mathrm{Na}^{+} / \mathrm{K}^{+}$-ATPase activity was FHM > FHME > FHMEl. The ouabain-sensitive $\mathrm{Na}^{+} / \mathrm{K}^{+}$-ATPase activity of each mutant was significantly lower than that of the wild-type protein, and there was no significant difference among all mutant groups. Whole-cell voltage-clamp recordings in HEK293T cells showed that the ouabain-sensitive pump currents of G615R were significantly reduced, while those of G762S and R938P were comparable to those of the wild-type strain.

\footnotetext{
* Correspondence: yusy1963@126.com; yushengyuan@301hospital.com.cn

${ }^{\dagger}$ Yingji Li and Wenjing Tang contributed equally to this work.

${ }^{1}$ Department of Neurology, The First Medical Center of Chinese PLA General Hospital, Fuxing Road 28, Haidian District, 100853 Beijing, China

Full list of author information is available at the end of the article
}

(C) The Author(s). 2021 Open Access This article is licensed under a Creative Commons Attribution 4.0 International License, which permits use, sharing, adaptation, distribution and reproduction in any medium or format, as long as you give appropriate credit to the original author(s) and the source, provide a link to the Creative Commons licence, and indicate if changes were made. The images or other third party material in this article are included in the article's Creative Commons licence, unless indicated otherwise in a credit line to the material. If material is not included in the article's Creative Commons licence and your intended use is not permitted by statutory regulation or exceeds the permitted use, you will need to obtain permission directly from the copyright holder. To view a copy of this licence, visit http://creativecommons.org/licenses/by/4.0/ The Creative Commons Public Domain Dedication waiver (http://creativecommons.org/publicdomain/zero/1.0/) applies to the data made available in this article, unless otherwise stated in a credit line to the data. 
Conclusions: ATP1A2 mutations cause phenotypes ranging from pure FHM to FHM with epilepsy and intellectual disability due to varying degrees of deficits in biochemical and electrophysiological properties of $\mathrm{Na}^{+} / \mathrm{K}^{+}$-ATPase. Mutations associated with intellectual disability presented with severe impairment of $\mathrm{Na}^{+} / \mathrm{K}^{+}$-ATPase. Whether epilepsy is accompanied, or the type of epilepsy did not seem to affect the degree of impairment of pump function.

Keywords: Familial hemiplegic migraine, ATP1A2, $\mathrm{Na}^{+} / \mathrm{K}^{+}$-ATPase, Patch clamp

\section{Background}

Hemiplegic migraine (HM) is characterized by severe migraine attacks with aura symptoms, including reversible motor weakness, usually affecting one side of the body and accompanied by visual, sensory, or language symptoms [1]. In some cases, patients experience additional neurological phenomena, such as coma [2-4], ataxia $[5,6]$, and seizures [7-10]. Individuals usually fully recover between episodes, but some patients develop permanent neurological manifestations involving cerebellar signs $[11,12]$ and intellectual disability $[8,13$, 14]. Familial hemiplegic migraine (FHM) is diagnosed when at least one first- or second-degree relative also suffers HM attacks [1]. To date, mutations in the $C A C N$ $A 1 A, A T P 1 A 2$, and SCN1A genes have been identified in FHM, and the corresponding forms are referred to as FHM1, FHM2, and FHM3, respectively [1]. In particular, more than ninety mutations were reported in $A T P 1 A 2$, and two-thirds of HMs were familial and dominantly inherited [15]. The clinical presentation of FHM2 with mutations in the same gene varies from pure FHM to severe variant forms with epilepsy and intellectual disability, but the correlation of these symptoms with different ATP1A2 mutations is still unclear.

The ATP1A2 gene encodes the $\alpha 2$ subunit of $\mathrm{Na}^{+} / \mathrm{K}^{+}$ATPase, which is a membrane-bound protein belonging to the P-type ATPase family [16]. Four different $\alpha$ isoforms are expressed in cells from different tissues [17]. ATP1A2 is predominantly expressed in astrocytes of the adult brain [18], while ATP1A3 is neuron-specific and mainly associated with alternating hemiplegia of childhood (AHC). It has been established that in addition to FHM2, mutations in ATP1A2 can also lead to AHC [12, 19] accompanied by mental retardation with or without epilepsy, suggesting a clinical overlap with FHM. Studies have shown that ATP1A3 mutations can be grouped by disease severity [20-22], but the clinical phenotypic spectrum has not been systematically studied for ATP1A2 mutations.

Previously, we reported a novel ATP1A2 mutation, G762S, that caused pure familial hemiplegic migraine [23], which inspired us to study the functional properties of FHM with different neurological symptoms. Therefore, this study aimed to systematically assess the phenotypic spectrum of previously reported ATP1A2 mutations, investigate the functional impairment of ten mutations in the cytoplasmic domain that have not been fully characterized and correlate FHM2 phenotypes with the specific functional effects of mutations to better understand the characteristics of ATP1A2 mutations, and to provide new perspectives for the pathogenesis, diagnosis, and treatment of similar diseases.

\section{Materials and methods cDNA constructs}

Full-length human ATP1A2 (NM_000702) and ATP1B1 (NM_001677) cDNAs were purchased from OriGene (pCMV6-AT1A2-Entry, Cat\#RC208606; pCMV6AT1B1-Entry, Cat\#RC200500, OriGene Technologies, Inc., Rockville, USA) and subcloned into the vectors pEF1 $\alpha$-IRES-AcGFP1 and pEF1 $\alpha$-IRES-DsRed-Express2, respectively. The wild type (WT) was designed containing p.Q116R and p.N127D to reduce ouabain sensitivity. Ten of previously identified variants were introduced to ATP1A2 cDNA: R65W (c.193 C > T), R202Q (c.605G > A), T378N (c.1133 C>A), R548C (c.1642 C>T), R593W (c.1777 C > T), G615R (c.1843G >A), D718N (c.2152G > A), G762S (c.2284G > A), E825K (c.2473G > A), and R938P (c.2813G > C). Site-directed mutagenesis was carried out by PCR with specific primers using Invitrogen $^{\text {Tx }} \quad$ Platinum $^{\text {Tx }} \quad$ SuperFi $^{\mathrm{im}}$ DNA Polymerase (Cat\#12,351,050, Invitrogen, Thermo Fisher Scientific, USA) as we previously described [23]. The recombinant fragments were amplified with PCR. The cDNA concentrations were determined by a microvolume spectrophotometer (Pultton P100/P100+, San Jose, CA, USA). Whole-insert sequencing was performed to verify the DNA sequence identity.

\section{HeLa cells and HEK293T cells}

HeLa cells and HEK293T cells were kindly provided by Dr. Weidong Han (Department of Bio-Therapeutic, Chinese PLA General Hospital, Beijing, China) and cultured with high-glucose DMEM (Dulbecco's modified Eagle's medium) containing $1 \%$ penicillin-streptomycin and $10 \%$ fetal bovine serum in $5 \% \mathrm{CO}_{2}$ at $37{ }^{\circ} \mathrm{C}$. Cells within 20 passages were used for transient transfection using Lipofectamine 3000 (Cat\#L3000015, Invitrogen, Carlsbad, CA, USA) in reduced-serum Opti-MEM. HEK293T cells were grown in 6-well dishes and 
transfected with ATP1A2 (WT and/or mutant constructs) and $A T P 1 B 1$ at a ratio of 2:1. After $48 \mathrm{~h}$ of transfection, cells were reseeded on poly-L-lysine-coated glass slips for electrophysiological recordings.

\section{Transient transfection and cell survival assay}

HeLa and HEK293T cells were seeded in 96-well dishes at 10,000 cells per well. Twenty-four hours after plating, cells were transfected with cDNA constructs of $0.1 \mu \mathrm{g}$ per well. After $24 \mathrm{~h}$ of transfection, $1 \mu \mathrm{M}$ ouabain was added to the medium, which can inhibit endogenous $\mathrm{Na}^{+} / \mathrm{K}^{+}$-ATPase without affecting ouabain-resistant pumps [24]. Cell viability was assessed at $12 \mathrm{~h}, 24 \mathrm{~h}$, $36 \mathrm{~h}, 48 \mathrm{~h}, 60 \mathrm{~h}$, and $72 \mathrm{~h}$ after exposure to ouabain using a methyl thiazolyl tetrazolium (MTT) reduction assay kit (BB-4201, BestBio, Shanghai, China). Another set of experiments tested the cell survival rate in the absence of ouabain. Formazan salt formation was monitored at $492 \mathrm{~nm}$ using a Multiskan FC Microplate Photometer (Thermo Scientific, USA). All experiments were carried out at least 3 times, with each data point performed in quintuplicate. The survival rate of the transfected groups was calculated relative to that of nontransfected controls.

\section{Isolation of membrane fractions and western blotting}

Total and plasma membranes from HeLa cells were isolated using a Minute ${ }^{\text {TM }}$ Plasma Membrane Protein Isolation and Cell Fractionation Kit (Cat\#SM-005, Invent Biotechnologies, Inc., Plymouth, USA). After 48 h of transfection, approximately $5 \times 10^{7}$ cells were collected and sensitized by Buffer A. The ruptured cell membranes and intact nuclei were obtained by passing through the proprietary filter twice with centrifuging at $16,000 \times \mathrm{g}$ for $30 \mathrm{~s}$. The total membranes were collected by centrifuging the resuspended pellet at $700 \times \mathrm{g}$ for $1 \mathrm{~min}$ and subsequently centrifuging the supernatant for $30 \mathrm{~min}$ at $16,000 \times \mathrm{g}$. For isolation of plasma membranes, the total membrane pellet was resuspended in Buffer B and centrifuged at $7800 \times \mathrm{g}$ for $5 \mathrm{~min}$. The supernatant was transferred to a fresh tube with $1.6 \mathrm{ml}$ cold PBS and centrifuged at $16,000 \times \mathrm{g}$ for $30 \mathrm{~min}$.

The whole steps were performed at $4{ }^{\circ} \mathrm{C}$. All buffers included $1 \mathrm{mM}$ phenylmethylsulfonyl fluoride (PMSF) and cOmplete ULTRA protease inhibitor cocktail tablets (Cat\#05892970001, Roche Diagnostics GmbH, Mannheim, Germany). The pelleted membranes were stored at $-70{ }^{\circ} \mathrm{C}$ and resuspended in Minute ${ }^{\mathrm{T \omega}}$ Denaturing Protein Solubilization Reagent (Cat\#WA-009, Invent Biotechnologies, Inc., USA) before western blotting. A bicinchoninic acid (BCA) protein assay kit (Cat\#E16201, GenStar, Beijing, China) was used to determine the protein concentration.
Approximately $10 \mu \mathrm{g}$ of solubilized protein sample was mixed with SDS-PAGE loading buffer, separated on an SDS gel containing $8 \%$ acrylamide and blotted on a polyvinylidene difluoride membrane. The $\alpha 2$ subunit of $\mathrm{Na}^{+} / \mathrm{K}^{+}$-ATPase was detected by rabbit monoclonal antibody [EPR11896(B)] (dilution 1:1000, ab166888, Abcam, Cambridge, UK), and membranes were incubated overnight at $4{ }^{\circ} \mathrm{C}$. Horseradish peroxidase-labeled goat antirabbit IgG $(\mathrm{H}+\mathrm{L})$ (1:750, Cat\#A0208, Beyotime Biotechnology, Shanghai, China) was used as a secondary antibody. An $\alpha$-tubulin rabbit polyclonal antibody (1:1000, Cat\#AF0001, Beyotime Biotechnology, Shanghai, China) was used as a protein loading control. ECL chemiluminescence reagent (Cat\#SL1350, Coolaber Science \& Technology Co., Beijing, China) was used for imaging. All experiments were carried out at least three times in two separate clones. The relative intensity of western blotting was analyzed using ImageJ.

\section{$\mathrm{Na}^{+} / \mathrm{K}^{+}$-ATPase activity test}

ATPase can decompose ATP to generate ADP and Pi (inorganic phosphorus). The activity of ATPase can be evaluated by measuring the amount of Pi. HeLa cells were harvested after $48 \mathrm{~h}$ of transfection and washed with cold saline to make a $10^{7} / \mathrm{ml}$ cell suspension. Then, a homogenizer was used to disrupt the cells. The BCA protein assay kit (Cat\#E162-01, GenStar, Beijing, China) was used to determine the protein concentration. $\mathrm{Na}^{+} /$ $\mathrm{K}^{+}$-ATPase activity was determined following the manufacturer's instructions for the Ultra Trace Sodium Potassium ATPase Test Kit (Cat\#A070-2, Nanjing Jiancheng Bioengineering Institute, China). Approximately $100 \mu \mathrm{l}$ membranes were combined with reagents $\mathrm{A}, \mathrm{B}$ and $\mathrm{C}$ and incubated at $37{ }^{\circ} \mathrm{C}$ for $30 \mathrm{~min}$, after which reagent $\mathrm{D}$ was added to terminate the enzymatic reaction. The mixture was centrifuged at $3500 \mathrm{rpm}$ for $10 \mathrm{~min}$. The supernatant was then extracted for measurement of the phosphorus concentration. After adding the developer and maintaining at room temperature for $5 \mathrm{~min}$, the absorbance of each tube was measured at $636 \mathrm{~nm}$. Ouabain $(10 \mu \mathrm{M}$ or $100 \mu \mathrm{M})$ was added to inhibit endogenous ATPase. Ouabain-sensitive ATPase activity was determined by subtracting the amount of Pi formed in the presence of $10 \mu \mathrm{M}$ and $100 \mu \mathrm{M}$ ouabain. All experiments were performed in triplicate in at least four separate clones.

\section{HEK293T whole-cell patch clamp}

Electrophysiological recordings were made at room temperature $\left(22-24^{\circ} \mathrm{C}\right)$ using an EPC 10 USB amplifier (HEKA Elektronik GmbH, Lambrecht/Pfalz, Germany). Patch pipettes were pulled by a MODEL P-97 Flaming/ Brown Micropipette Puller (Sutter Instrument, Novato, USA) using borosilicate glass capillaries (Item\#: BF150- 
86-10, Sutter Instrument, Novato, CA, USA). The pump current was recorded with an electrode resistance of 3-4 $\mathrm{M} \Omega$ in buffer containing (in mM) $95 \mathrm{NaMeSO}_{4}, 20$ TEA-Cl, $2 \mathrm{BaCl}_{2}, 5$ EGTA, 4 Mg-ATP, 5 Trisphosphocreatine, 10 HEPES, 5 glucose, $\mathrm{pH}$ adjusted to 7.35 with $\mathrm{NaOH}, 290$ mOsm. The extracellular solution contained (in $\mathrm{mM}$ ): $140 \mathrm{NaCl}, 1 \mathrm{MgCl}_{2}, 2 \mathrm{BaCl}_{2}, 2$ $\mathrm{CsOH}, 2 \mathrm{NiCl}_{2}, 0.2 \mathrm{CdCl}_{2}, 0.33 \mathrm{NaH}_{2} \mathrm{PO}_{4}, 5$ HEPES, 5 glucose, 20 NMDG-Cl, pH adjusted to 7.35 with $\mathrm{HCl}$, and 320 mOsm [25]. All recording solutions included 1 $\mu \mathrm{M}$ ouabain to block endogenous pumps. Cells were continuously held at $-30 \mathrm{mV}$ or $+40 \mathrm{mV}$ and perfused with a $\mathrm{K}^{+}$-free solution. The pump current was activated by superfusing cells with an extracellular solution containing $20 \mathrm{mM} \mathrm{KCl}$ instead of $20 \mathrm{mM}$ NMDG-Cl. For the analysis of voltage dependence, currents were elicited with $200 \mathrm{~ms}$ test steps from -100 to $+100 \mathrm{mV}$, increased by $+20 \mathrm{mV}$, and at a $-70 \mathrm{mV}$ holding potential. Then, $10 \mu \mathrm{M}$ ouabain was added to measure the ouabain-sensitive current. Recordings were sampled at $50 \mathrm{kHz}$ and filtered at $5 \mathrm{kHz}$.

\section{Homology modeling}

We performed homology modeling in SWISS-MODEL using the sequence of human $\alpha 2$ isomer (UniProt IDs P50993) based on crystal structures of the $\mathrm{Na}^{+} / \mathrm{K}^{+}$ATPase from the bovine kidney (Protein Data Bank accession number 4XE5 recently solved at $3.9 \AA$ resolution) [26], with which it shares $86.95 \%$ sequence identity. Three-dimensional models of the human $\mathrm{Na}^{+}$/ $\mathrm{K}^{+}$- ATPase were analyzed by the PyMOL(TM) Molecular Graphics System (Version 2.3.0).

\section{Statistical analysis}

Electrophysiological data were analyzed using FitMaster v2 $\times 90.2$ (HEKA Elektronik GmbH, Lambrecht/Pfalz, Germany). Statistics and plotting were performed using R software 3.6 (R Foundation for Statistical Computing, Vienna, Austria). Statistical analysis was performed with one-way ANOVA (Tukey HSD test for multiple comparisons) or Kruskal-Wallis tests. The current-voltage curves (or MTT cell survival assays) were compared with a two-way ANOVA. Linear regression was used to calculate the correlation between the age of first HM onset and $\mathrm{Na}^{+} / \mathrm{K}^{+}$-ATPase activity. Data are presented as the mean \pm standard error (SE) with a significance level of $P<0.05$.

\section{Results}

\section{ATP1A2 mutations and clinical phenotypic spectrum}

All missense mutations are shown in the structural schematic diagram of the $\alpha 2$ subunit (Fig. 1a), of which $67.5 \%$ were familial and $32.5 \%$ were sporadic. Phenotypes associated with epilepsy and intellectual disability were mostly reported in familial cases, accounting for 48.2 and $21.4 \%$, respectively. The crystal structure of $\mathrm{Na}^{+} / \mathrm{K}^{+}$-ATPase from the bovine kidney (4XE5) was used as a template for homology modeling. ATP1A2 missense mutations were marked by the associated clinical symptoms: pure HM, HM with epilepsy, HM with ataxia, and HM with intellectual disability (with or without epilepsy). From the top view of the intracellular loops (Fig. 1b), we found that mutations causing HM with intellectual disability were closer to the phosphorylation site. Ten mutations at the cytoplasmic domain were studied to explore the relationships between phenotypic spectrum and function (Fig. 1c), which were from the literature search and our previous reports (Supplementary Table 1). Of these mutations, four cause pure FHM (R65W, R202Q, R593W, and G762S), three cause FHM with epilepsy (R548C, E825K, and R938P), and three cause FHM/AHC with epilepsy and intellectual disability (G615R, D718N, and T378N). The detailed sources and pedigrees of the studied FHM families are included in the Supplementary Material.

\section{ATP1A2 expression remained unchanged between the mutant and wild type}

ATP1A2 mutations with distinct phenotypes were grouped as pure FHM (FHM), FHM with epilepsy (FHME), and FHM with epilepsy and intellectual disability (FHMEI). We found that ATP1A2 mutations did not affect the levels of either total membrane proteins or plasma membrane proteins. The relative intensities of western blot analysis (Fig. 2a and b) showed a slight reduction in the mutant plasma membrane protein compared to WT that was not statistically significant $(P>$ 0.05, Kruskal-Wallis test).

\section{ATP1A2 mutations reduced cell survival under ouabain}

The transfection efficiency, as estimated by the fluorescence intensity, showed no significant differences between the mutants and WT (Supplementary Fig. 1). We found a significantly reduced survival rate of mutants compared with WT in all three groups $(P<0.0001$, twoway ANOVA, Fig. $2 \mathrm{c}$ and $\mathrm{d}$ ), indicating that the mutant pump significantly affected the function of the $\mathrm{Na}^{+} / \mathrm{K}^{+}$ATPase. The individual mutants also showed a reduced survival rate compared with that of WT pumps in HeLa cells (R65W: $P=0.032$, other mutants: $P<0.0001$, twoway ANOVA) and HEK293T cells (R65W: $P=0.016$, other mutants: $P<0.0001$, two-way ANOVA) (Supplementary Figs. 2 and 3). In the absence of ouabain, the survival rates of cells in each mutant group were similar to those in the WT group (Supplementary Fig. 4). 


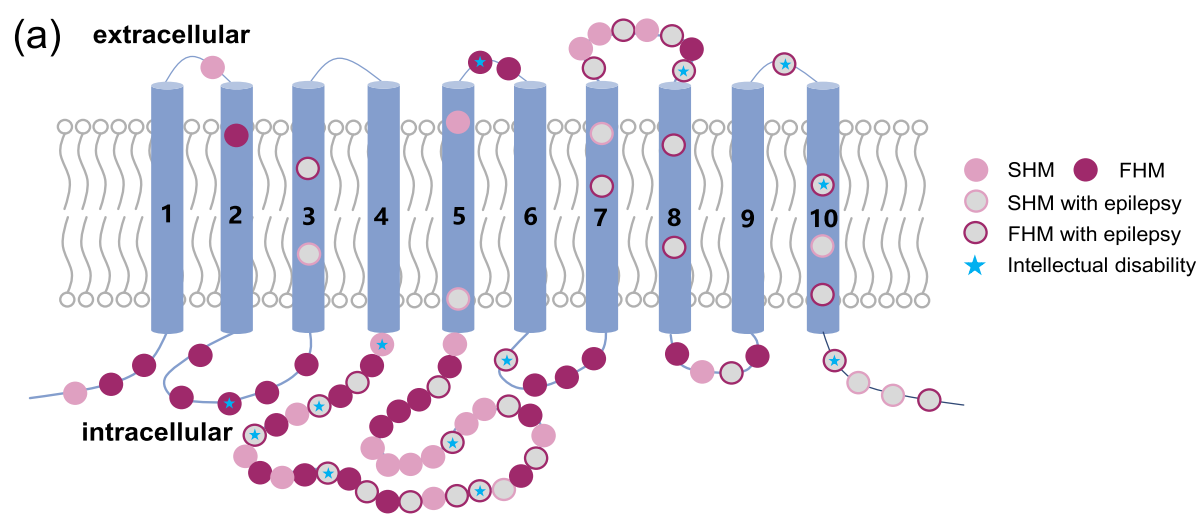

(b)

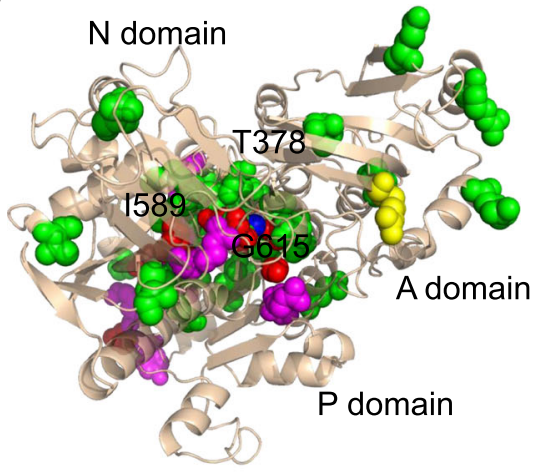

(c)

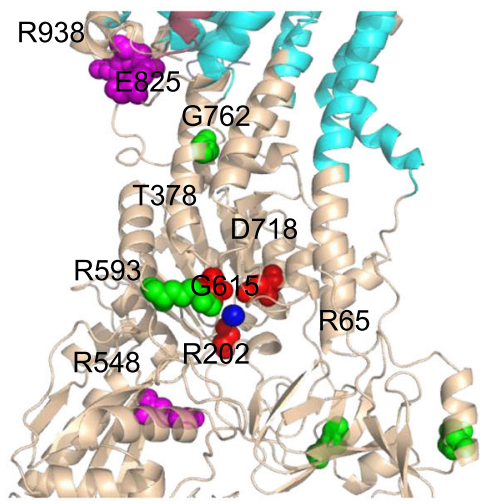

Fig. 1 Structural location of ATP1A2 mutations. a Phenotypic distribution of ATP1A2 missense mutations (colored circles, $n=83$ ). Ten transmembrane segments are shown as blue cylinders. b ATP1A2 mutant residues are shown as spheres and divided into four groups: pure HM (green), HM with epilepsy (magenta), HM with ataxia (yellow) and HM with intellectual disability (with or without epilepsy) (red) according to the clinical symptoms of patients. The intracellular loops are shown in the top view, indicating that mutations causing severe HM (accompanied by intellectual disability) were closer to $\mathrm{Mg}^{2+}$ (blue) near the phosphorylation site. c The structural locations and phenotypes of the ten mutations investigated in this study

The $\mathrm{Na}^{+} / \mathrm{K}^{+}$-ATPase activity of the ATP1A2 mutant was associated with the phenotypic spectrum

We found that the $\mathrm{Na}^{+} / \mathrm{K}^{+}$-ATPase activity of each mutant was lower than that of the WT in the absence of ouabain (Fig. 3a, $P<0.01$ ), and similar results were obtained in the presence of $10 \mu \mathrm{M}$ ouabain (Fig. 3b, $P<$ 0.05). In the presence of $100 \mu \mathrm{M}$ ouabain, compared with WT, only the R548C, E825K, T378N, G615R and D718N mutations showed reduced $\mathrm{Na}^{+} / \mathrm{K}^{+}$-ATPase activity $(P<0.05)$, while R65W, R2020Q, R593W, G762S and R938P showed $\mathrm{Na}^{+} / \mathrm{K}^{+}$-ATPase activity similar to that of WT protein (Fig. 3c, $P>0.05$ ). Of note, the $\mathrm{Na}^{+} /$ $\mathrm{K}^{+}$-ATPase activity of WT was decreased under $10 \mu \mathrm{M}$ and $100 \mu \mathrm{M}$ ouabain compared with that in the absence of ouabain $(P<0.0001)$. When mutations were divided according to their FHM phenotypes, we found that in the absence and presence of $10 \mu \mathrm{M}$ ouabain, the $\mathrm{Na}^{+}$/ $\mathrm{K}^{+}$-ATPase activity of the WT was higher than that of the mutants in all phenotype groups (Fig. 3d compared with WT, $P<0.0001)$. Of interest, the overall $\mathrm{Na}^{+} / \mathrm{K}^{+}$ATPase activity of mutations causing FHMEI was significantly lower than that of mutations causing FHM $(P<0.0001)$ and FHME $(P=0.0003)$ in the presence of $10 \mu \mathrm{M}$ ouabain. However, there was no significant difference between FHM and FHME mutations $(P=0.294)$. In the presence of $100 \mu \mathrm{M}$ ouabain, the level of $\mathrm{Na}^{+} / \mathrm{K}^{+}$ATPase activity was as follows: WT $>$ FHM $>$ FHME $>$ FHMEI. Specifically, the $\mathrm{Na}^{+} / \mathrm{K}^{+}$-ATPase activity of WT was significantly higher than that of mutants associated with FHM $(P=0.012)$ and FHME $(P=0.002)$ and FHMEI $(P<0.0001)$; the $\mathrm{Na}^{+} / \mathrm{K}^{+}$-ATPase activity of FHM mutants was significantly higher than that of FHME $(P=0.040)$ and FHMEI $(P<0.0001)$ mutants; and the $\mathrm{Na}^{+} / \mathrm{K}^{+}$-ATPase activity of FHME mutants was significantly higher than that of FHMEI mutants $(P=$ 0.0003).

We further analyzed the ouabain-sensitive $\mathrm{Na}^{+} / \mathrm{K}^{+}$ATPase activity in the presence of $10 \mu \mathrm{M}$ and $100 \mu \mathrm{M}$ ouabain (Fig. 3e). The ouabian-sensitive $\mathrm{Na}^{+} / \mathrm{K}^{+}$-ATPase activity was calculated by subtracting the total $\mathrm{Na}^{+} / \mathrm{K}^{+}$ATPase activity obtained under different concentrations of ouabain from that obtained without ouabain. 


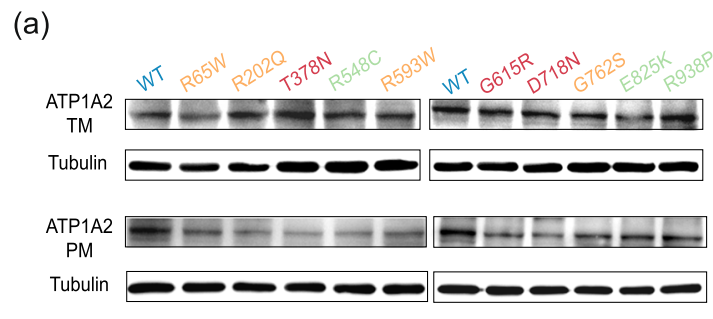

(c)

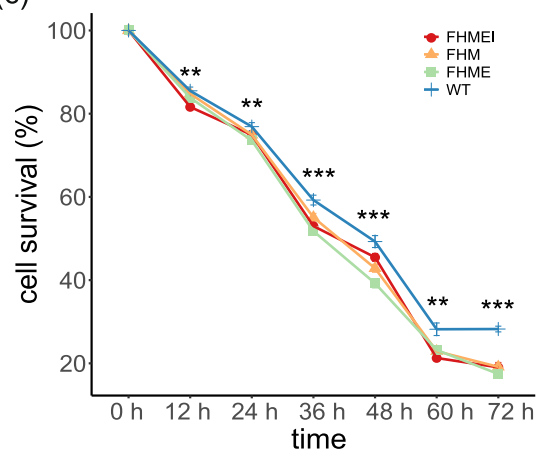

(d)
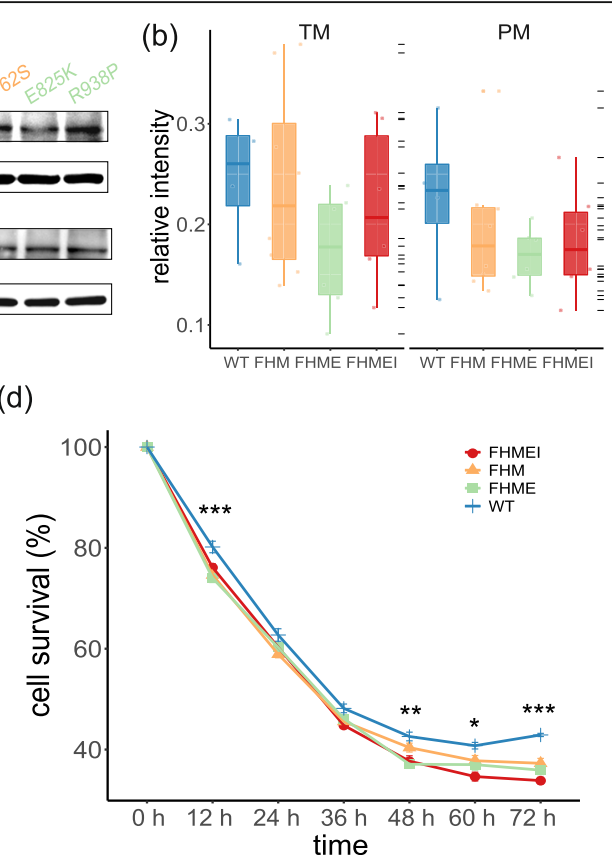

Fig. 2 Expression and cell viability of mutant $\mathrm{Na}^{+} / \mathrm{K}^{+}$-ATPase. a Western blot of total membrane and plasma membrane proteins expressed in transfected HeLa cells (ATP1A2: 102 kDa; Tubulin: 50 kDa). The colored labels represented different groups: blue, WT; yellow, FHM; green, FHME; red, FHMEl. $\mathbf{b}$ The ATP1A2 expression of mutants was equal to that of the WT (compared with WT, TM: $P=0.3822$, PM: $P=0.5507$, Kruskal-Wallis test). $\mathbf{c}$ and $\mathbf{d}$ Cell survival assays. All mutants showed a significantly reduced survival rate under $1 \mu \mathrm{M}$ ouabain in both HEK293T (c) and HeLa (d) cells $(P<0.0001$, two-way ANOVA)

Consistent with the above findings, the ouabain-sensitive $\mathrm{Na}^{+} / \mathrm{K}^{+}$-ATPase activity of WT was significantly higher than that of the mutant groups at $10 \mu \mathrm{M}$ ouabain (compared with WT: FHME, $P=0.002$, FHM and FHMEI, $P<0.0001)$, while no significant difference was found among mutant groups $(P>0.05)$. Similarly, in the presence of $100 \mu \mathrm{M}$ ouabain, the $\mathrm{Na}^{+} / \mathrm{K}^{+}$-ATPase activity of the WT group was significantly higher than that of the mutant group $(P<0.0001)$.

We drew a scatter plot based on the phenotypic information in Supplementary Table 1 (Fig. 4a). Consistent with our above results, the mutant $\mathrm{Na}^{+} / \mathrm{K}^{+}$-ATPase activity associated with intellectual disability was low, and whether epilepsy was accompanied, or the type of epilepsy did not seem to have an effect on $\mathrm{Na}^{+} / \mathrm{K}^{+}$-ATPase activity. We also noticed that patients with epilepsy and intellectual disability were younger at first HM attack, while patients with pure FHM were older at first attack. The regression analysis was conducted between age at first $\mathrm{HM}$ attack and $\mathrm{Na}^{+} / \mathrm{K}^{+}$-ATPase activity, but no statistical significance was found (Fig. $4 \mathrm{~b}-\mathrm{d}, P>0.05$ ).

\section{The mutation causing a severe phenotype showed lower pump currents}

HEK293T cells were continuously held at $-30 \mathrm{mV}$ or + $40 \mathrm{mV}$ to record pump currents in the WT pump (Fig. $5 \mathrm{a}$ and $\mathrm{b})$. The pump current was activated by superfusion of $20 \mathrm{mM} \mathrm{K}^{+}$and inhibited by $10 \mu \mathrm{M}$ ouabain (Fig. 5c). Cells with co-fluorescence expression were selected for electrophysiological recording (Fig. 5d). We found that the ouabain-sensitive pump current in the mutant was slightly reduced for G762S and R938P compared to the WT $\mathrm{Na}^{+} / \mathrm{K}^{+}$-ATPase (Fig. 5e, G762S, $P=$ 0.185 , R938P, $P=0.443$, two-way ANOVA) with no statistically significant difference. In G615R, the ouabainsensitive pump currents were significantly reduced and close to zero (Fig. 5e, $P=0.042$, two-way ANOVA). However, at $+40 \mathrm{mV}$, the ouabain-sensitive pump currents of G762S $(14.91 \pm 4.12 \mathrm{pA})$ and G615R (4.98 \pm 1.61 $\mathrm{pA})$ were significantly decreased compared to those of WT $(40.56 \pm 5.20 \mathrm{pA}, P<0.05)$, and P938P $(19.06 \pm$ $13.48 \mathrm{pA}$ ) showed currents comparable to those of WT $(P>0.05)$.

\section{Discussion}

Since the first report associated mutations of the $\mathrm{Na}^{+} /$ $\mathrm{K}^{+}$-ATPase $\alpha$ subunit with heritable disease [9], the phenotypic spectrum of mutations in this gene has been expanding considerably. Most ATP1A2 mutations cause familial or sporadic hemiplegic migraine, some accompanied by ataxia [5], a range of epilepsies (from benign familial infantile convulsions to generalized epilepsy with febrile seizures plus $[7,10]$ ) or intellectual disability $[4$, 27]. In this study, we compared the effect of $A T P 1 A 2$ 

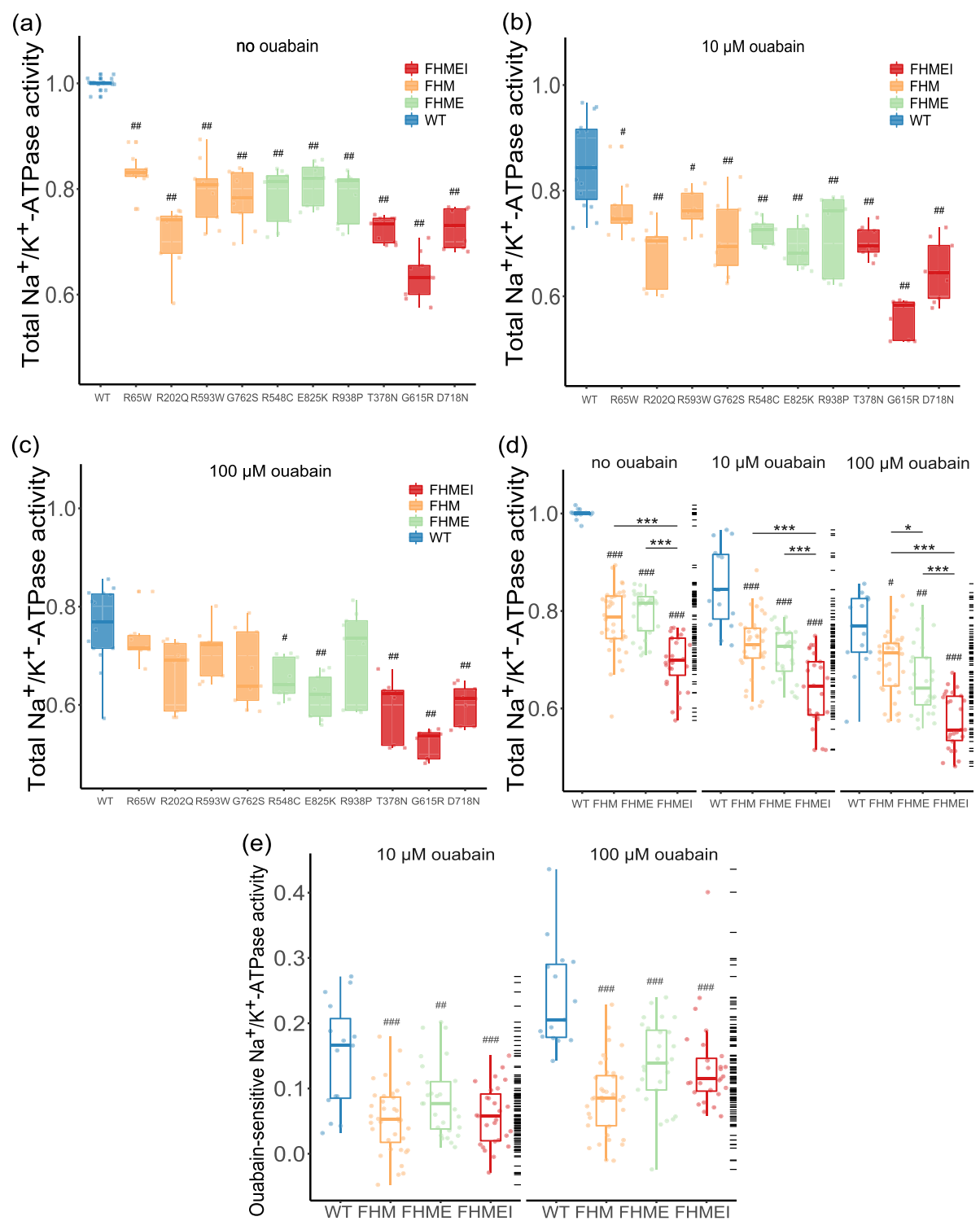

Fig. $3 \mathrm{Na}^{+} / \mathrm{K}^{+}$-ATPase activity test. a-c Na $/ \mathrm{K}^{+}$-ATPase activity of each mutant in the absence and presence of $10 \mu \mathrm{M}$ or $100 \mu \mathrm{M}$ ouabain. The activity of the $\mathrm{Na}^{+} / \mathrm{K}^{+}$-ATPase was normalized to that of the WT Na ${ }^{+} / \mathrm{K}^{+}$-ATPase without ouabain. $\mathbf{d} \mathrm{Na}^{+} / \mathrm{K}^{+}$-ATPase activity with and without ouabain. Mutations were divided into three groups according to their FHM phenotypes. e The ouabain-sensitive ATPase activity of the WT pump was higher than that of mutant pumps in the presence of $10 \mu \mathrm{M}$ and $100 \mu \mathrm{M}$ ouabain. $P$ value compared with the WT: ${ }^{P} P<0.05,{ }^{\# \#} P<0.01$,

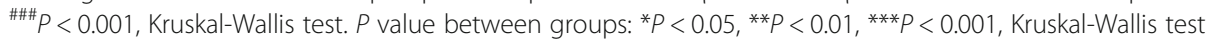

mutations covering this phenotypic spectrum of FHM2 to understand the underlying mechanisms and to correlate genotypes with phenotypes.

\section{Functional consequences of ATP1A2 mutations}

Our results suggested that all mutant constructs expressed a level of protein (total membrane or plasma membrane) similar to that of the WT pump. This indicated that ATP1A2 mutants did not affect the synthesis or targeting of $\mathrm{Na}^{+} / \mathrm{K}^{+}$-ATPase. In vertebrates, the $\beta$ subunit acts as an important ancillary subunit of $\mathrm{Na}^{+}$/ $\mathrm{K}^{+}$-ATPase, which mainly assists in correct protein folding, membrane insertion, and plasma membrane delivery [17]. In this study, the ten included mutations were all located in the intracellular domain, so there was little interaction of these residues with the $\beta$ subunit. Of note, both the expression vector used and the culture temperature have important effects on protein expression and function [28], which makes it difficult to reach consistent conclusions in comparison to previous studies. Most ATP1A2 mutations showed protein levels similar to those of the WT $[29,30]$. Mutations associated with reduced total or plasma membrane protein levels were either located in transmembrane helices, such as 


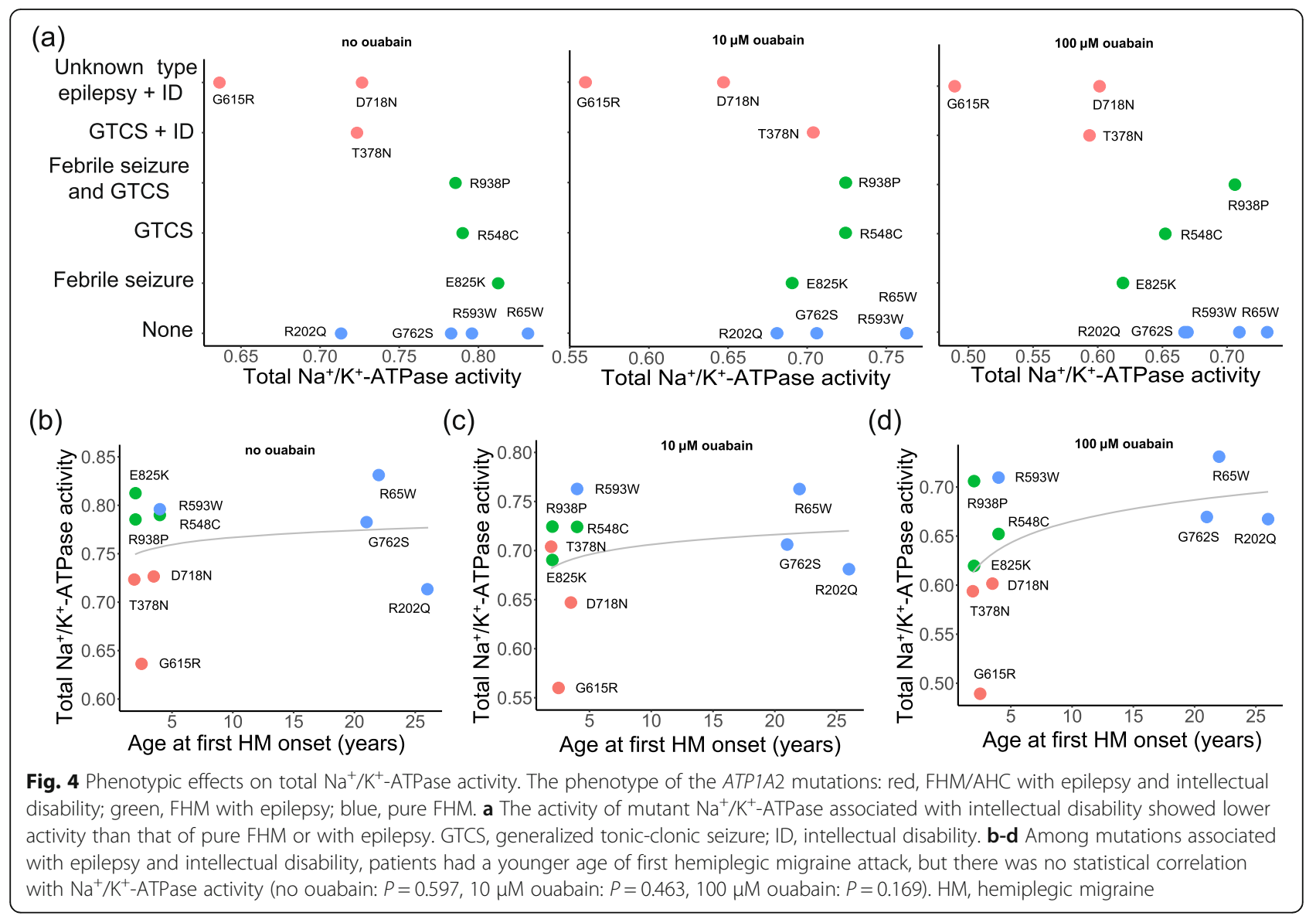

G301R [2] and G855R [31]; interacted with the $\beta$ subunit directly or indirectly, such as W887R [32] and R908Q [28]; or were more severe mutation types, such as del(K935_S940)ins(Ile) [29], S996fs [29] and L994del [31]. This suggested that missense mutations in intracellular domains had little effect on membrane protein expression and that there may be other mechanisms that contribute to the pathogenicity of these mutations. Similar results were obtained in the study of $A T P 1 A 3$ [33], although AHC tends to be more severe than rapid-onset dystonia-parkinsonism, no difference in protein expression was found between groups. In this study, all mutations showed decreased cell survival under $1 \mu \mathrm{M}$ ouabain compared with the WT, but there were no differences among the mutant groups. In fact, we found that almost all ATP1A2 mutations reported in previous studies resulted in a significant decrease in cell viability, whether in HeLa cells or HEK293T cells. Although we speculated that mutations causing more severe accompanying symptoms might show significantly reduced plasma membrane levels and cell survival, it was difficult to correlate those functional damages with the severity of disease based on previous research and the current results.
At present, most assays of mutant $\mathrm{Na}^{+} / \mathrm{K}^{+}$-ATPase activity have been performed in SF9 insect cells [30, 34], while a few studies involving C515Y [35] and L764P [36] have used Xenopus oocytes. Most ATP1A2 mutations showed significantly reduced ouabain-sensitive $\mathrm{Na}^{+} / \mathrm{K}^{+}$ATPase activity, while only a few mutants, including Y9N, R51H, E174K, T345A, R897Q, and R879W [30, 34], showed activity similar to that of WT. The mutants with normal $\mathrm{Na}^{+} / \mathrm{K}^{+}$-ATPase activity were all associated with pure FHM, pure SHM or the more common migraine with or without aura, which suggested that ouabain-sensitive $\mathrm{Na}^{+} / \mathrm{K}^{+}$-ATPase activity may be related to the disease severity. Of interest, we found a correlation between the severity of the FHM phenotype and the total $\mathrm{Na}^{+} / \mathrm{K}^{+}$-ATPase activity rather than ouabainsensitive $\mathrm{Na}^{+} / \mathrm{K}^{+}$-ATPase activity, which has not been considered in previous studies. In our experiments, ouabain was added to inhibit the endogenous $\mathrm{Na}^{+} / \mathrm{K}^{+}$ATPase activity, so the ouabain-sensitive $\mathrm{Na}^{+} / \mathrm{K}^{+}$ATPase activity here more represented the endogenous part. We believed that the total $\mathrm{Na}^{+} / \mathrm{K}^{+}$-ATPase activity represented the exogenous pump activity of transfection, and this part of the $\mathrm{Na}^{+} / \mathrm{K}^{+}$-ATPase activity was found to related to the severity of the disease. 

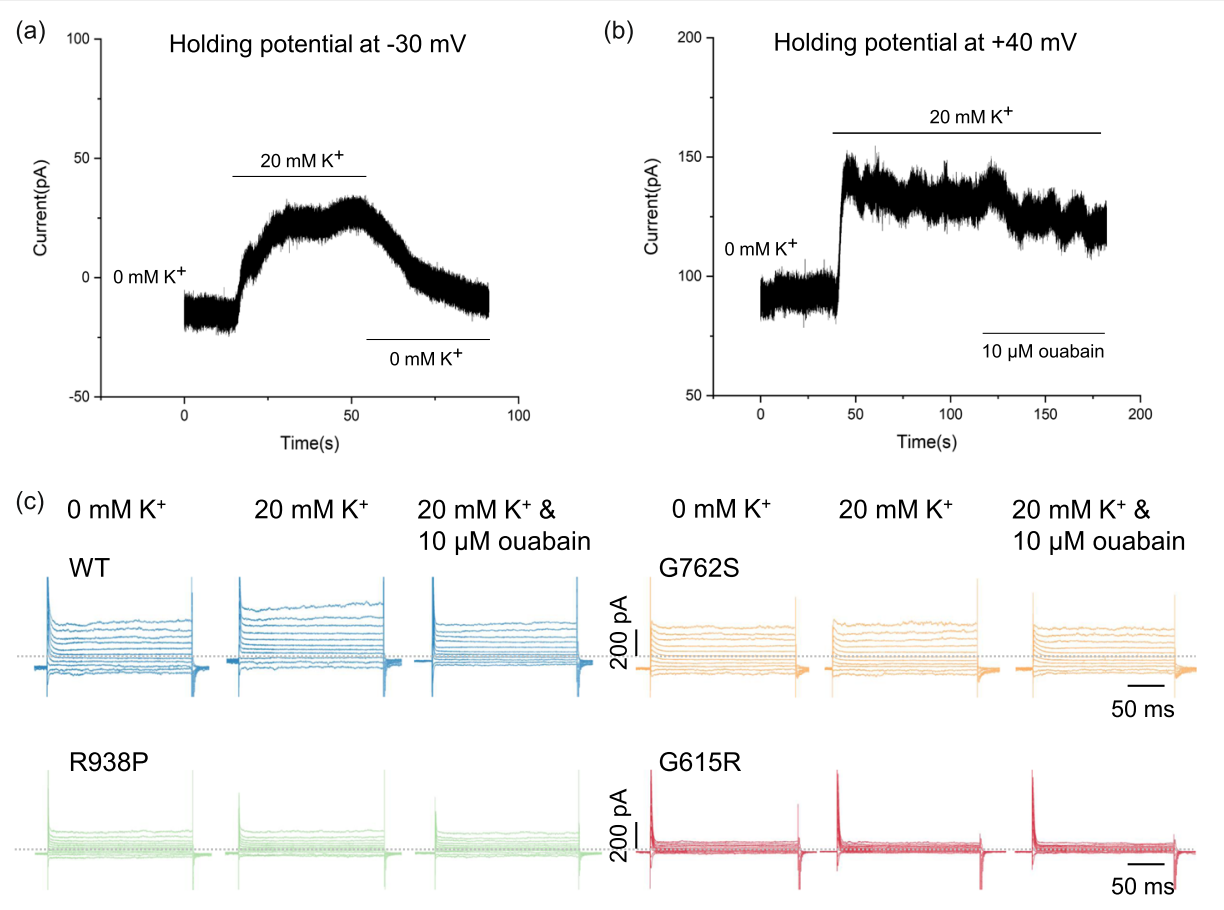

(d)
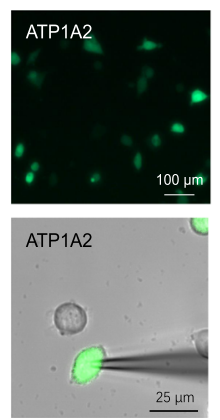
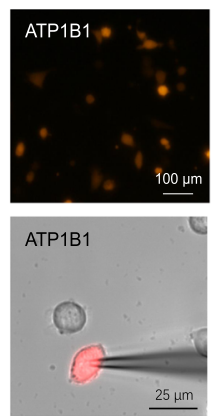

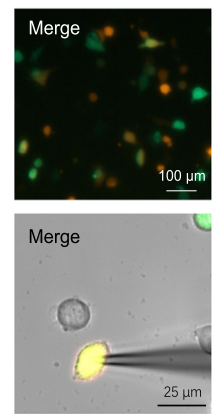

(e)

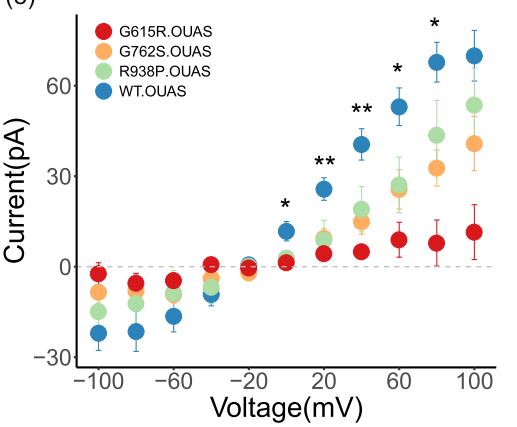

Fig. 5 Pump current recordings of $\mathrm{Na}^{+} / \mathrm{K}^{+}$-ATPase transfected in HEK293T cells. a and b Continuous recordings with wild-type pumps in HEK293T cells. $1 \mu \mathrm{M}$ ouabain was added to block endogenous pumps. The pump current was activated by superfusion of $20 \mathrm{mM} \mathrm{K}^{+}$and inhibited by 10 MM ouabain. c Representative raw currents of WT (blue), G762S (yellow), R938P (green) and G615R (red) in response to 200 ms steps with +20 $\mathrm{mV}$ increments from -100 to $+100 \mathrm{mV}$. d Coexpression of ATP1A2 (green) and ATP1B1 (red) in transfected HEK293T cells. e Ouabain-sensitive pump currents measured in the last $50 \mathrm{~ms}$ of test pulses (two-way ANOVA: $P=0.040$ ) (amplitude at $+40 \mathrm{mV}$, one-way ANOVA compared with $\mathrm{WT}, n=9 ; \mathrm{G} 762 \mathrm{~S}, n=10, P=0.018 ; \mathrm{R} 938 \mathrm{P}, n=8, P=0.142 ; \mathrm{G} 615 \mathrm{R}, n=10, P=0.008)$

Pump currents were recorded in homologous HEK293T cells. We found reduced ouabain-sensitive pump currents for the G615R mutant protein compared with the WT pump, while no difference was found for G762S or R938P. This result was consistent with our findings for $\mathrm{Na}^{+} / \mathrm{K}^{+}$-ATPase activity, indicating a correlation between the pump current and the severity of FHM neurological accompanying symptoms. In previous studies, variants showing reduced or undetectable pump currents mainly involved severe mutations such as L994del, del(K935_S940) ins(Ile), and S966fs [29]. In addition, mutations near the C-terminal ion pathway, D999H, Y1009X, and R937P [31], also presented decreases in pump current. This suggested that there may be a link among the structural location, FHM phenotype and functional impairment.

\section{Genotype-phenotype correlation and impact of ATP1A2 pathogenic variants}

For the first time, we studied the relationship of different phenotypes in ATP1A2 mutations with functional impairment. All investigated mutations showed similar levels of protein expression to that of the WT and decreased cell viability, demonstrating that as a rough estimate of pump function, the membrane expression and cell survival assays cannot distinguish FHM phenotypes of different severities. We argued that amplitudes of $\mathrm{Na}^{+} / \mathrm{K}^{+}$-ATPase activity and pump currents are related 
to the FHM phenotypes, and whether it was accompanied by epilepsy, or the type of epilepsy had little effect on $\mathrm{Na}^{+} / \mathrm{K}^{+}$-ATPase activity. A recent review demonstrated that among the three monogene mutations causing FHM, most cases associated with epilepsy occurred in ATP1A2 mutations [37]. However, the prognosis of epilepsies was benign [37]. In addition, our study found that functional changes of epilepsy-related mutations are similar to mutations associated with pure FHM, indicating that intellectual disability was an important indicator of severe functional impairment of the mutant pump. Severely decreased $\mathrm{Na}^{+} / \mathrm{K}^{+}$-ATPase activity and a reduction in pump currents were found in the G615R mutation causing FHM with epilepsy and intellectual disability. Two sporadic cases that were reported with a different amino acid change, G615E, showed HM with generalized tonic-clonic seizures, and another sporadic case carrying the G615E mutation was diagnosed with cognitive and motor delay at two years old, indicating the structural importance of G615 [4]. Of note, G615R was associated with an incomplete penetrance of $2 / 5$ of intellectual disability and $4 / 5$ of epilepsy in heritable cases. Thus, both the mutation itself and other genetic or environmental factors contribute to the individual phenotype.

$\mathrm{Na}^{+} / \mathrm{K}^{+}$-ATPase uses the energy derived by ATP hydrolysis to transport three $\mathrm{Na}^{+}$out of the cell and two $\mathrm{K}^{+}$into the cell [16]. Our results reveal that varying degrees of $\mathrm{Na}^{+} / \mathrm{K}^{+}$-ATPase loss-of-function exist in different FHM phenotypes, supporting a haploinsufficiency mechanism. It is expected to impair the reuptake of $\mathrm{K}^{+}$ and glutamate in the synaptic crevices, thus leading to hyperexcitability of the brain and increased susceptibility to cortical spreading depression (CSD), which is associated with migraine auras. Mutations in the ion transport genes CACNA1A, ATP1A2 and SCN1A can lead to familial hemiplegic migraine, indicating genetic heterogeneity. Previous studies suggested that gain-of-function FHM1 mutations were associated with increased susceptibility to CSD. However, a recent study reported a de novo CACNA1A mutation causing hemiplegic migraine and developmental delay but without epilepsy, revealing a loss-of-function of $\mathrm{Ca}_{\mathrm{v}} 2.1$ channel [38]. This confirmed that different functional consequences may occur in patients with intellectual disability. Our study also demonstrated that severely decreased $\mathrm{Na}^{+} / \mathrm{K}^{+}$-ATPase activity and a reduction in pump currents were only found in mutations associated with intellectual disability. These findings suggest that hemiplegic migraine, epilepsy, and intellectual disability may have a common pathogenesis, that is, damage to sodium-potassium pump function. And different degrees of damage lead to different neurological manifestations. It is known that severe epilepsy is often accompanied by intellectual disability, but intellectual disability can also occur without seizures. Recent studies on sodium channels showed that mutations causing intellectual disability with or without epilepsy manifested as different effects on channel function and neuronal firing $[39,40]$. Although our results suggest that mutations associated with intellectual disability manifest as more severe pump impairment, their role in glial cells and their relationship with neuronal firing are still unclear. More extensive neuron-related research should be conducted in the future, and the study of neuron networks and mouse models is essential for understanding the mechanism of nervous system disease.

\section{Conclusions}

In conclusion, this study provides a comprehensive delineation of the phenotypic spectrum with ATP1A2 mutations ranging from pure FHM to FHM with epilepsy and/or intellectual disability. We argue that ATP1A2 mutations cause a variety of phenotypes that are well correlated with distinct consequences of the mutations on biochemical and biophysical properties. Mutations associated with intellectual disability often cause more serious functional impairment and need to be given more attention.

\section{Abbreviations \\ FHM2: Familial hemiplegic migraine type 2; AHC: Alternating hemiplegia of childhood; WT: Wild type; CSD: Cortical spreading depression}

\section{Supplementary Information}

The online version contains supplementary material available at https://doi. org/10.1186/s10194-021-01309-4.

\begin{abstract}
Additional file 1: Supplementary Figure 1. Representative images of transfection efficiency of wild-type and mutant constructs with $100 \mu \mathrm{m}$ scales. Supplementary Figure 2. Survival assays in HeLa cells. The survival rate of each mutant was significantly reduced compared to the wild-type (R65W: $P=0.032$, other mutants: $P<0.0001$, two-way ANOVA). Supplementary Figure 3. Survival assays in HEK293T cells. The survival rate of each mutant was significantly reduced compared to the wild-type (R65W: $P=0.016$, other mutants: $P<0.0001$, two-way

ANOVA). Supplementary Figure 4. Survival assays in HeLa cells in the absence of ouabain. The survival rates of cells in each mutant group were similar to those in the WT group ( $P>0.05$, two-way ANOVA). Supplementary Table 1. Clinical characteristics of previously published patients with studied ATP1A2 mutations.
\end{abstract}

\section{Acknowledgements}

We thank Dr. Zhenwei Liu for his comments on the design and operation of electrophysiological experiments.

\section{Authors' contributions}

S. Yu, R. Liu and Z. Dong conceived and designed the project. Y. Li and S. Kong performed the molecular biology experiments. L. Kang and D. Zhao performed the biochemical experiments. Y. Li and W. Tang performed the electrophysiological recordings and statistical analysis and drafted the manuscript. S. Yu performed a critical revision of the manuscript. The author(s) read and approved the final manuscript. 


\section{Funding}

This work was supported by the National Natural Science Foundation of China [grant numbers: 82071226, 81671077] and Natural Science Foundation of Beijing Municipality [grant number: Z170002].

\section{Availability of data and materials}

The datasets used and/or analyzed during the current study are available from the corresponding author on reasonable request.

\section{Declarations}

\section{Ethics approval and consent to participate}

Not applicable.

\section{Consent for publication}

Not applicable.

\section{Competing interests}

The authors report no competing interests.

\section{Author details}

'Department of Neurology, The First Medical Center of Chinese PLA General Hospital, Fuxing Road 28, Haidian District, 100853 Beijing, China. ${ }^{2}$ School of Medicine, Nankai University, 300071 Tianjin, China.

\section{Received: 4 June 2021 Accepted: 2 August 2021}

\section{Published online: 12 August 2021}

\section{References}

1. Headache Classification Committee of the International Headache Society (IHS) (2018) The International Classification of Headache Disorders, 3rd edition. Cephalalgia 38:1-211. https://doi.org/10.1177/0333102417738202

2. Santoro L, Manganelli F, Fortunato MR et al (2011) A new Italian FHM2 family: Clinical aspects and functional analysis of the disease-associated mutation. Cephalalgia 31:808-819. https://doi.org/10.1177/03331024113993 51

3. Deprez L, Weckhuysen S, Peeters K et al (2008) Epilepsy as part of the phenotype associated with ATP1A2 mutations. Epilepsia 49:500-508. https:// doi.org/10.1111/j.1528-1167.2007.01415.x

4. Riant F, Ducros A, Ploton C et al (2010) De novo mutations in ATP1A2 and CACNA1A are frequent in early-onset sporadic hemiplegic migraine. Neurology 75:967-972. https://doi.org/10.1212/WNL.0b013e3181f25e8f

5. Thomsen LL, Kirchmann M, Bjornsson A et al (2007) The genetic spectrum of a population-based sample of familial hemiplegic migraine. Brain 130: 346-356. https://doi.org/10.1093/brain/awl334

6. Fernandez DM, Hand CK, Sweeney BJ, Parfrey NA (2008) A novel ATP1A2 gene mutation in an Irish familial hemiplegic migraine kindred. Headache 48:101-108. https://doi.org/10.1111/j.1526-4610.2007.00848.x

7. Vanmolkot KRJ, Kors EE, Hottenga JJ et al (2003) Novel mutations in the $\mathrm{Na}+, \mathrm{K}+-$ ATPase pump gene ATP1A2 associated with familial hemiplegic migraine and benign familial infantile convulsions. Ann Neurol 54:360-366. https://doi.org/10.1002/ana.10674

8. Roth C, Freilinger T, Kirovski G et al (2014) Clinical spectrum in three families with familial hemiplegic migraine type 2 including a novel mutation in the ATP1A2 gene. Cephalalgia 34:183-190. https://doi.org/10.1177/0333102413 506128

9. De Fusco M, Marconi R, Silvestri L et al (2003) Haploinsufficiency of ATP1A2 encoding the $\mathrm{Na}+/ \mathrm{K}+$ pump a2 subunit associated with familial hemiplegic migraine type 2. Nat Genet 33:192-196. https://doi.org/10.1038/ng1081

10. Costa C, Prontera P, Sarchielli P et al (2014) A novel ATP1A2 gene mutation in familial hemiplegic migraine and epilepsy. Cephalalgia 34:68-72. https:// doi.org/10.1177/0333102413498941

11. Jurkat-Rott K, Freilinger T, Dreier JP et al (2004) Variability of familial hemiplegic migraine with novel A1A2 Na+/K+-ATPase variants. Neurology 62:1857-1861. https://doi.org/10.1212/01.WNL.0000127310.11526.FD

12. Swoboda K, Kanavakis E, Xaidara A et al (2004) Alternating hemiplegia of childhood or familial hemiplegic migraine?: A novel ATP1A2 mutation. Ann Neurol 55:884-887. https://doi.org/10.1002/ana.20134

13. Castro M-J, Stam A, Lemos C et al (2008) First mutation in the voltage-gated NaV 1.1 subunit gene SCN1A with co-occurring familial hemiplegic migraine and epilepsy. Cephalalgia 10:308-313. https://doi.org/10.1212/NXG. 0000000000000303

14. Wilbur C, Buerki SE, Guella I et al (2017) An Infant With Epilepsy and Recurrent Hemiplegia due to Compound Heterozygous Variants in ATP1A2. Pediatr Neurol 75:87-90. https://doi.org/10.1016/j.pediatrneurol.2017.06.003

15. Friedrich T, Tavraz NN, Junghans C (2016) ATP1A2 mutations in migraine: Seeing through the facets of an ion pump onto the neurobiology of disease. Front Physiol 7:1-21. https://doi.org/10.3389/fphys.2016.00239

16. Skou JC, Esmann M (1992) The Na,K-ATPase. J Bioenerg Biomembr 24:249261. https://doi.org/10.1007/BF00768846

17. Blanco G (2005) Na,K-ATPase subunit heterogeneity as a mechanism for tissue-specific ion regulation. Semin Nephrol 25:292-303. https://doi.org/1 0.1016/j.semnephrol.2005.03.004

18. McGrail KM, Phillips JM, Sweadner KJ (1991) Immunofluorescent localization of three Na,K-ATPase isozymes in the rat central nervous system: Both neurons and glia can express more than one Na,K-ATPase. J Neurosci 11: 381-391. https://doi.org/10.1523/jneurosci.11-02-00381.1991

19. Bassi MT, Bresolin N, Tonelli A et al (2004) A novel mutation in the ATP1A2 genes causes alternating hemiplegia of childhood. J Med Genet 41:621-628. https://doi.org/10.1136/jmg.2003.017863

20. Li M, Jazayeri D, Corry B et al (2015) A functional correlate of severity in alternating hemiplegia of childhood. Neurobiol Dis 77:88-93. https://doi. org/10.1016/j.nbd.2015.02.002

21. Holm R, Toustrup-Jensen MS, Einholm AP et al (2016) Neurological disease mutations of a3 Na+,K+-ATPase: Structural and functional perspectives and rescue of compromised function. Biochim Biophys Acta - Bioenerg 1857: 1807-1828. https://doi.org/10.1016/j.bbabio.2016.08.009

22. Sweadner KJ, Arystarkhova E, Penniston JT et al (2019) Genotype-structurephenotype relationships diverge in paralogs ATP1A1, ATP1A2, and ATP1A3. Neurol Genet 5:309-333. https://doi.org/10.1212/NXG.0000000000000303

23. Tang W, Zhang M, Qiu E et al (2019) A Chinese family with familial hemiplegic migraine type 2 due to a novel missense mutation in ATP1A2. Cephalalgia 39:1382-1395. https://doi.org/10.1177/0333102419847738

24. Price EM, Lingrel JB (1988) Structure-Function Relationships in the Na,KATPase a Subunit: Site-directed Mutagenesis of Glutamine-111 to Arginine and Asparagine-122 to Aspartic Acid Generates a Ouabain-resistant Enzyme. Biochemistry 27:8400-8408. https://doi.org/10.1021/bi00422a016

25. Simmons CQ, Thompson $\mathrm{CH}$, Cawthon BE et al (2018) Direct evidence of impaired neuronal Na/K-ATPase pump function in alternating hemiplegia of childhood. Neurobiol Dis 115:29-38. https://doi.org/10.1016/j.nbd.2018.03.009

26. Gregersen JL, Mattle D, Fedosova NU et al (2016) Isolation, crystallization and crystal structure determination of bovine kidney Na+,K+-ATPase. Acta Crystallogr Sect Struct Biol Commun 72:282-287. https://doi.org/10.1107/S2 053230X1600279X

27. Castro MJ, Nunes B, de Vries B et al (2008) Two novel functional mutations in the Na+, K+ -ATPase a2-subunit ATP1A2 gene in patients with familial hemiplegic migraine and associated neurological phenotypes. Clin Genet 73:37-43. https://doi.org/10.1111/j.1399-0004.2007.00918.x

28. Tavraz NN, Dürr KL, Koenderink JB et al (2009) Impaired plasma membrane targeting or protein stability by certain ATP1A2 mutations identified in sporadic or familial hemiplegic migraine. Channels 3:82-87. https://doi.org/1 $0.4161 /$ chan.3.2.8085

29. Tavraz NN, Friedrich T, Dürr KL et al (2008) Diverse functional consequences of mutations in the Na+/K+-ATPase a2-subunit causing familial hemiplegic migraine type 2. J Biol Chem 283:31097-31106. https://doi.org/10.1074/jbc. M802771200

30. Weigand KM, Swarts HGP, Russel FGM, Koenderink JB (2014) Biochemical characterization of sporadic/familial hemiplegic migraine mutations. Biochim Biophys Acta - Biomembr 1838:1693-1700. https://doi.org/10.1016/ j.bbamem.2014.03.022

31. Spiller $\mathrm{S}$, Friedrich $\mathrm{T}$ (2014) Functional analysis of human $\mathrm{Na}(+) / \mathrm{K}(+)$-ATPase familial or sporadic hemiplegic migraine mutations expressed in Xenopus oocytes. World J Biol Chem 5:240-253. https://doi.org/10.4331/wjbc.v5.i2.240

32. Capendeguy O, Horisberger JD (2004) Functional effects of $\mathrm{Na+}, \mathrm{K}+-$-ATPase gene mutations linked to familial hemiplegic migraine. NeuroMolecular Med 6:105-116. https://doi.org/10.1385/NMM:6:2-3:105

33. Lazarov E, Hillebrand M, Schröder S et al (2020) Comparative analysis of alternating hemiplegia of childhood and rapid-onset dystonia-parkinsonism ATP1A3 mutations reveals functional deficits, which do not correlate with disease severity. Neurobiol Dis 143:105012. https://doi.org/10.1016/j.nbd.202 0.105012 
34. Swarts HGP, Weigand KM, Venselaar H et al (2013) Familial hemiplegic migraine mutations affect Na,K-ATPase domain interactions. Biochim Biophys Acta - Mol Basis Dis 1832:2173-2179. https://doi.org/10.1016/j.bba dis.2013.08.003

35. Todt U, Dichgans M, Jurkat-Rott $K$ et al (2005) Rare missense variants in ATP1A2 in families with clustering of common forms of migraine. Hum Mutat 26:315-321. https://doi.org/10.1002/humu.20229

36. Koenderink JB, Zifarelli G, Qiu LY et al (2005) Na,K-ATPase mutations in familial hemiplegic migraine lead to functional inactivation. Biochim Biophys Acta - Biomembr 1669:61-68. https://doi.org/10.1016/j.bbamem.2 005.01.003

37. Hasırcı Bayır BR, Tutkavul K, Eser M, Baykan B (2021) Epilepsy in patients with familial hemiplegic migraine. Seizure 88:87-94. https://doi.org/10.1016/j. seizure.2021.03.028

38. Indelicato E, Boesch S (2021) From Genotype to Phenotype: Expanding the Clinical Spectrum of CACNA1A Variants in the Era of Next Generation Sequencing. Front Neurol 12:1-10. https://doi.org/10.3389/fneur.2021.63 9994

39. Liu Y, Schubert J, Sonnenberg L et al (2019) Neuronal mechanisms of mutations in SCN8A causing epilepsy or intellectual disability. Brain 142: 249-250. https://doi.org/10.1093/brain/awy326

40. Wolff M, Johannesen KM, Hedrich UBS et al (2017) Genetic and phenotypic heterogeneity suggest therapeutic implications in SCN2A-related disorders. Brain 140:1316-1336. https://doi.org/10.1093/brain/awx054

\section{Publisher's Note}

Springer Nature remains neutral with regard to jurisdictional claims in published maps and institutional affiliations.

Ready to submit your research? Choose BMC and benefit from:

- fast, convenient online submission

- thorough peer review by experienced researchers in your field

- rapid publication on acceptance

- support for research data, including large and complex data types

- gold Open Access which fosters wider collaboration and increased citations

- maximum visibility for your research: over $100 \mathrm{M}$ website views per year

At $\mathrm{BMC}$, research is always in progress.

Learn more biomedcentral.com/submissions 